\title{
Interview with M. David Merrill: Half a Century of Experience in the Field of Educational Technology and Instructional Design
}

\author{
Ali Simsek \\ Anadolu University, Turkey
}

M. David Merrill is a leading figure in the field of educational technology and instructional design. He has been contributing to our field for about half a century. His contributions have particularly focused on instructional strategies and fundamental learning principles more than the use of educational media and their influences. He has devised a number of instructional design theories, developed technology-based instructional systems, led large-scale educational technology projects, conducted studies testing the effects of various instructional variables on different learning outcomes, and trained many researchers who have contributed to our field.

Considering his major accomplishments and world-known impact in the field of educational technology and instructional design, we thought that it would be a good idea to have an interview with him. Unfortunately, I was located in Turkey and he was living in the United States so that we have conducted this interview not face-to-face but with the help of contemporary technology. We have completed the interview in several rounds. First, I sent him the questions and he replied to them. Then, I asked for more details and he provided with further elaborations. Finally, we both read and agreed on what to be published.

As presented here, the interview contains information about how M. David Merrill got interested in the field of educational technology and instructional design, what important contributions he has provided over the years, how he evaluates the current status of the field, and what prospects he foresees for the future. I think that the interview gives the reader a very good flavor of M. David Merrill's professional as well as personal experiences, contributions, disappointments, and dreams about our field.

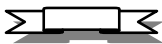

\section{When did you start working in the field of educational technology?}

After receiving a B.A. degree from Brigham Young University in 1961, I entered graduate school at the University of Illinois, Champaign/Urbana in the fall of the same year. I was 24 years old when I began, and I graduated with my Ph.D. in 1964 at the age of 27.

\section{Which particular program was it?}

My graduate program was called The Psychology of Classroom Learning but in fact it was all about teaching machines and computer based instruction. 


\section{How did the field of educational technology look like at that time?}

Computer Based Instruction (CBI) was in its infancy and the handful of graduate students under supervision of Larry Stolurow were on the extreme cutting edge of this movement. Stolurow was one of the early leaders in $\mathrm{CBI}$. He wrote one of the first monographs on computer based instruction. [Stolurow, L. M. (1961). Teaching by machine. Washington DC: US Department of Health, Education, and Welfare]. As his graduate students, we had our own CBI system built around an IBM 1600 computer (the number is bits of memory) that controlled a rear projection microfilm reader. It was called the "Socrates system."

\section{What were the dominant paradigms or hot issues?}

The dominant technology was educational television; everyone had a television studio. The dominant theory was behaviorism. B. F. Skinner's teaching machines were the hot item. [Skinner, B. F. (1958). Teaching machines. Science, 128, 969-977].

Skinner's approach was linear. Norman Crowder had an alternative approach with branching from page/frame to page/frame. Both were implemented in machines that were thought to revolutionize the schools and both approaches were implemented in books form. Our Computer Based Training (CBT) system was a Crowder AutoTutor machine controlled by a computer. It is interesting that Skinner's linear approach did not catch on but the branching paradigm is still the underlying paradigm for much CBI.

\section{Who were the leading figures that impressed you most?}

The leading figures for me were my professors at the University of Illinois. There were many that were very influential in the field: Nate Gage, Lee Cronbach, Richard Anderson, David Ausubel, etc.

I was particularly influenced by a pioneer book: [Lumsdain, A. A. \& Glaser, R. (1960). Teaching machines and programmed learning: A Source Book. Washington DC: National Education Association Department of Audio Visual Instruction]. It was followed shortly after I received my Ph.D. degree by a second edition. [Glaser, R. (1965). Teaching machines and programmed learning II. Washington, DC: National Education Association Department of Audio Visual Instruction].

Note that the Department of Audio Visual Instruction is the forerunner of the Association for Educational Communications and Technology (AECT), which was formed after I finished my graduate training.

Early work on concept learning by Bruner and his colleagues also influenced me and led to our own work on teaching concepts. [Bruner, J. S., Goodnow, J. J., \& Austin, G. A. (1956). A study of thinking. New York: John Wiley \& Sons].

Perhaps the greatest influence on me during graduate school was Robert Gagne. I read his book in manuscript form during my last year of graduate study. My early work was largely an attempt to extend his work, and his influence on my thinking is still evident in my current work on First Principles of Instruction. [Gagne, R. M. (1965). The conditions of learning. New York: Holt, Rinehart \& Winston]. 


\section{Have you ever worked together with Robert Gagne?}

Gagne has had more influence on my career than any other individual. I was first introduced to him when I read his Conditions of Learning in manuscript form in 1964. This work had a significant influence on my thinking.

I was on many panels with Gagne at AECT and AERA. At one point we both worked with the Air Force Armstrong Laboratory in San Antonio, Texas. However our projects were somewhat different. The most extensive interaction was our Conversation on Instructional Design held at Utah State University in July 10, 1987. This six-hour conversation was recorded on video and is available now as a CD. David Twitchell, who was a Ph.D. student of mine at the time, prepared an edited transcript of this conversation which was published in a series of articles in Educational Technology Magazine in 1990 and 1991 (Volume 30, Issue 7 through Volume 31, Issue 1).

The year following our conversation at Utah State University, Gagne and I met at the American Academy of Science in Washington D.C. for 5 days, 6 hours a day, for a private conversation on instructional design. This 30-hour conversation was recorded but due to technical difficulties the conversation was never transcribed. Following this conversation, Gagne and I wrote an article together. [Gagné, R. M. \& Merrill, M. D. (1990). Integrative goals for instructional design. Educational Technology Research and Development, 38(1), 23-30].

My final tribute to Robert Gagne was the opportunity to summarize his contributions at a memorial conference held in his honor after his death at Florida State University.

\section{What specifically drove you into this field at the beginning?}

I entered college at age 18 with the idea of becoming an electrical engineer. At 20 I served as a missionary for The Church of Jesus Christ of Latter-Day Saints for the next two years. I was assigned to work in Ohio, Indiana, and Michigan. We went from door to door telling folks about our church. I was impressed at this time that our teaching was ineffective. I began to think about better ways that we could teach. I even wrote several short essays on how we could teach better as missionaries during this period of time.

When I returned to school, engineering had lost all interest for me (perhaps because of my poor grades in calculus and physics during my first two years of college). I decided to become a teacher and major in education. My father had been a teacher, and my grandfather had been a dean of education. However, the courses in the teacher preparation program were the worst courses I ever had. I did not feel I was learning anything there. I learned how to avoid getting sued, how to make a resource file, and how to pass out papers. However, there never seemed to be any information about how to make teaching effective.

I was about ready to give up and pursue some different career when I expressed my concerns to one of my professors, Asahel Woodruff. He sympathized with me about the poor quality of our courses but then gave me the following challenge which set me on the path I have since pursued. "You could go into a different career and you would probably be successful, but you could also decide that education could be improved and you could determine to make a difference and improve the field." He then suggested that there were doctoral programs that would accept me directly from my undergraduate work without having to work for several years in public schools. Not being one to walk away from a challenge, I decided to go to graduate school. 
I applied and was accepted by several schools. I chose the University of Illinois because they offered me a 3 year, all expenses paid, NDEA fellowship. Wrong reason to choose a school but serendipity stepped in and I ended up at one of the best graduate schools possible with the leaders in what would become the field of instructional technology.

\section{Which institutions have you worked during your career?}

Throughout my career, I worked at a number of universities and companies. The following is a short summary of my work at these institutions:

George Peabody College: I taught classes in measurement in the teacher education program. I had a 50\% time research assignment. I completed several research studies following up on my dissertation study.

Brigham Young University - Provo, Utah (1966-67; 1968-79: At the beginning I taught classes in the Innovative Secondary Teacher Education Program (ISTEP). Later I initiated a Ph.D. program in Instructional Technology. It became one of the leading programs in the country and is still active today. Our graduates include some of the current leaders in the field. Our curriculum was unique in that rather than formal classes we had a series of practicum experiences which involved students working under the mentorship of a faculty member on each of the following types of projects: a research/product review, a research or development proposal for funding, an instructional development project, an experimental research or evaluation project. These projects were prior to the dissertation project. The ideal was for these projects to represent an integrated program of research and development that led to the dissertation project. This curriculum is still in place today.

I founded the Center for Instructional Technology Research and Development (ITR\&D). I was responsible for hiring a number of faculty researchers at BYU. We published a working paper series that included about 40 working papers during this period, many of which later became research publications. While it has changed names several times, this organization is still active today.

I worked to bring the National Science Foundation (NSF) funded TICCIT project from the University of Texas to Brigham Young University. This included moving more than 15 personnel to Provo from Austin. TICCIT was a multimillion dollar project and one of two very large government CAI projects at the time. The other was PLATO. I directed the authoring system design team for this project. The result was a very unique learner controlled approach to CBT which has not yet been duplicated in other systems. The system was also unique in that it contained an expert system advisor, one of the first exert systems to be implemented. I was responsible for the design of the authoring system and the expert advisor system.

During this period of time, I also developed Component Display Theory. Working with Charles Reigeluth, we also developed Elaboration Theory. Both theories are major contributions to instructional technology and are still used/cited. Personnel in ITR\&D also undertook major NSF sponsored research on learner control, which was such a prominent part of the TICCIT system.

Stanford University (1967-68): I taught educational measurement classes in the teacher education program. I also had a research assignment in the Center for Teaching. 
Courseware Inc. (1974-1979): A group of the personnel on TICCIT formed a research and development company called Courseware Inc. The purpose of this company was to develop instructional materials using Component Display Theory and Instructional Systems. I served as the Vice President for Research until my resignation from the company in 1979. The research arm of this organization worked in cooperation with ITR\&D during its early years. This company developed training especially for military clients. It was finally sold to Anderson Consulting sometime in the early 1980's. It ceased operation in the late 1990's.

University of Southern California (1979-1987): For one year I taught classes in the Curriculum and Instruction Department including a course on futures. Then, I was appointed to the Instructional Technology Department where I taught classes on instructional design and research. For one year I served as department head.

Perceptronics (1982-86): For several years I had two full time appointments - one with the University of Southern California (USC) and the other with Perceptronics. I worked at Perceptronics during the day until late afternoon and then taught at USC in the later afternoon and evening. I worked at least 40 hours a week for each organization, a very busy period of time. I did a number of very interesting projects for Perceptronics which were not directly related to my former work. Perhaps one of the most unique was Action Code, which was using a bar code to provide instructional interactions to a video system. The idea was to have a text which included bar codes which when swiped would set up an instructional interaction on a video player. Action code included more than a dozen separate instructional sequences including multiple-choice questions and branching simulations. It was a very unique system which had only a short shelf life. Another unique project at Perceptronics was the design of a computer language to control robots built with a German construction toy.

Microteacher Inc. (1983-1986): Benny Lowery and I formed a company to build courseware for children and families. We originally developed this software for a company called EduWare that marketed the products. The company was later sold to Peachtree Software which eventually decided not to market the educational products. When Peachtree withdrew, Microteacher started to market our own products. The products included a Poetry Program, which I wrote and programmed. It also included a very successful reading program using the brand new speech synthesis software. Other programs were developed in writing, statistics, and story problems.

$I_{2}$ Research Group (1987-1997): Our R\&D focus was on automating instructional design. As a result, we developed a second generation of instructional design theory, hence the name $I_{2}$. We completed a number of related research and development projects. The most prominent of which was ID Expert, an attempt to build a general purpose expert authoring system. With the demise of the funding for ID Expert we developed other smart authoring systems including the Electronic Textbook (IDXelerator) and the Instructional Simulator (IDSimulator).

Utah State University (1987-2004): I taught classes in instructional design, instructional research, project management, and designing instructional materials. I started the USU Instructional Technology Summer Institute which continued every summer for fifteen years. This institute 
brought participants from around the world. The theme for the first ten years was Automating Instructional Design and focused on projects interested in building intelligent authoring systems.

In 2002 I wrote papers on First Principles of Instruction and A Pebble-in-the-Pond Model for instructional design. Both of these papers have had significant impact on the field. Since retiring from USU I have continued to write and investigate First Principles of Instruction.

For a more complete description of my major contributions see the following paper: [Merrill, M. D. (2008). Reflections on a four decade search for effective, efficient and engaging instruction. In M. W. Allen (Ed.), Michael Allen's 2008 e-Learning Annual (Vol. 1, pp. 141-167): Wiley Pfieffer].

\section{What was the rationale behind instructional research laboratories?}

In 1969 an associate dean at Brigham Young University asked me if I would establish a media research laboratory. I told him I was interested in instructional research not media research, so he said "then establish an instructional research laboratory". He allocated two full-time researcher slots, a full time secretary, space to work and a budget. How could I refuse? The Instructional Design and Development Laboratory in the College of Education became a leading research unit in the field. This organization is still in operation even though it has changed names several times during the past four decades.

The reason was to bring together researchers in a laboratory where we could study effective instruction. We published a series of working papers, contributed to conferences, and published much research on this topic.

I subsequently headed the research division of Courseware Inc., a private instructional development company.

At Utah State University we established the ID2 research group. This group was studying second generation instructional design in an attempt to build automated tools for doing instructional design. This resulted in ID Expert, the Electronic Textbook, and the Instructional Simulator. Each of these tools represented very innovative prototypes for tools which built in instructional design. We also sponsored a summer instructional design institute at Utah State University for 15 years that focused on the topic of automating instructional design.

Why did I establish instructional design and research labs? The reason is simple: It is highly rewarding to work with a group of very smart graduate students and other faculty members on a problem of common interest.

\section{What was your first serious work (research, project, publication)?}

I'm not sure which one deserves the first priority but I think the following is the answer to your question: [Merrill, M. D. (1965). Correction and review on successive parts in learning a hierarchical task. Journal of Educational Psychology, 56, 225-234]. The research reported in this article was conducted on the Socrates system, one of only a few studies ever completed on this early CBI system.

\section{How did you involve in TICCIT and what was your role there?}

There is a long story here but it is too involved for this interview. It includes how I got involved with Vic Bunderson, how he was eventually persuaded to come to Brigham Young University 
(BYU), how we moved the University of Texas Computer Based Instruction Laboratory to Provo and many other interesting details.

I led the team that developed the authoring system for TICCIT. Because TICCIT had a built in instructional design, it was unique and based on what became Component Display Theory. To this day, there has not been another authoring system that has incorporated built-in instructional design nor incorporated learner control of instructional strategy as was implemented in TICCIT. The advisor in TICCIT was also unique in that it involved one of the first overlay expert systems for advising the student.

I suggest the following publications for more details: (a) [Merrill, M. D., Schneider, E. W., \& Fletcher, K. A. (1980). TICCIT. Englewood Cliffs, NJ: Educational Technology Publications]; and (b) [Merrill, M. D. (1980). Learner control in computer-based learning. Computers and Education, 4, 77-95].

\section{What motivated you to start working on the Elaboration Theory?}

I felt that Gagne's hierarchical analysis of content was not sufficient, that we needed a more holistic approach. This was the driving motive behind it.

\section{What about the Component Display Theory?}

Component Display Theory (CDT) was developed simultaneously with the TICCIT system. Elaboration theory came after and it was our attempt to find a way to more adequately characterize instructional content. We felt that prerequisite relationships were not sufficient for describing content. Our current work on problem-centered instruction is an extension of the early work on Elaboration Theory.

\section{Can you tell us a little bit about your work with IBM and its results?}

I was on the IBM Educational Advisory Committee for several years along with a few other prominent folks in the field. Our job was to review their educational activities and advise them on how to make their instruction more effective. Latter IBM became one of the major sponsors of our work on ID Expert.

\section{Are you satisfied with interests of researchers in your work on Learning Objects?}

Unfortunately not! I feel that this is a very powerful idea that got lost. The problem was in the definition of learning objects. If you define learning objects as anything then you have nothing. One characteristic is reusability but there are more important relationships that got lost in the discussions of learning objects. I suggest that people read our papers on knowledge objects for more information about our thoughts related to learning objects: [Merrill, M. D. (2001). Components of instruction toward a theoretical tool for instructional design. Instructional Science, 29(4-5), 291-310].

\section{Have you reached your goals or expectations with the Transactions Theory?}

No! I still believe that we could build very sophisticated tools that would easily guide the instructional design process. Such tools would serve two important goals - decrease the cost of 
instructional design and development, and significantly increase the effectiveness and efficiency of instruction.

\section{Has your work on Concept Teaching made a significant contribution to the field?}

This is for others to judge but I do know that when our prescriptions for teaching concepts are followed the resulting instruction is more effective and efficient. There is indeed a good body of research proving our point.

\section{Do you still sum up instructional theories in the form of generations of principles?}

I suppose so. We devised the name "second generation instructional design" to indicate a move beyond traditional instructional design and our attempt to automate the process via expert system technology. Our thoughts related to this specific area are summarized in a couple of papers: (a) [Merrill, M. D., Li, Z., \& Jones, M. K. (1990). Limitations of first generation instructional design (ID1). Educational Technology, 30(1), 7-11]; and (b) [Merrill, M. D., Li, Z., \& Jones, M. K. (1990). Second generation instructional design (ID2). Educational Technology, 30(2), 7-14].

\section{Do you know the number of books, articles, book chapters, papers have you produced?}

There are 284 entries in my publication list but there are several recent papers not yet on the list so somewhere over 284 including journal articles, chapters in books, technical papers, and books.

\section{How many doctoral theses have you supervised?}

I'm not good at keeping lists. I made a list in 2002 that includes 47 . With my current students the list goes beyond 50 .

\section{How satisfied are you with the work of your students?}

It has been my opportunity to work with students who have become leaders in the field. Much of what I've accomplished I owe to work with my students. Most of my efforts have been collaborative with students. Many of the really good ideas have been contributed by students. Many of my students have taken and extended our work. Two notable examples are the work on Concept Learning by Robert Tennyson and the work on Elaboration Theory by Charles Reigeluth. However, there are many others.

\section{What did the AECT's Distinguished Service Award in 2001 mean to you?}

I was greatly honored to have been recognized. It has never been my goal to seek honor or position. In fact I have resisted seeking leadership in professional organizations; perhaps I should have contributed more in this regard. It is always gratifying to know that your work is being used and respected. However, there are many colleagues that contribute so much, and it is unfortunate that more are not recognized for their outstanding contributions.

\section{Is the field of educational technology where it should be now?}

No! I feel that we are abandoning our fundamental question - how to make instruction more effective, efficient and engaging. We have always been plagued by the pursuit of the latest technology rather than the pursuit of effective instruction. The current pursuit of learning 
communities, repositories of learning, and related technologies are important but I feel that they are not central to our mission.

\section{What do you recommend to young colleagues in the field?}

If it is worth writing, it is probably worth publishing or presenting at a national/international convention. You have great ideas, don't be intimidated. Make something up. That is, you have good ideas to contribute. Don't feel that your contribution is not worth making.

\section{When did you retire? Have you ever postponed it for academic reasons?}

If retirement means that I no longer have a salary from a university or any other organization than I retired in 2004 when I became an emeritus professor at Utah State University. However since that time I've spent three years at Brigham Young University-Hawaii as a volunteer professor and consultant on distance education, I've taught a class each semester (one in residence and the rest online) for three years for Florida State University as a visiting professor. I'm currently teaching an online class at BYU-Hawaii as a volunteer and I will be teaching a class at the University of Hawaii during the Winter semester 2010. I continue to consult and to write but I keep telling folks I'm retired. However, I do spend more time on my model railroad than in the past. See the progress on the railroad at http://atsgrr.blogspot.com

\section{What brought you to Hawaii and the ISD Center at BYU there?}

When we retire our church encourages us to volunteer as missionaries to serve in a wide variety of capacities throughout the world to help build up the church. Most of these are not proselyting but more in the realm of community service. I was asked to serve at BYU-Hawaii as an education missionary with the assignment to assist the faculty in putting their courses online for delivery to our students in country before they come to the campus. I served two years from 2004-2006 and again during 2008-2009.

\section{Do you have any academic plans for future or just enjoying your retirement?}

Hopefully a book will magically appear one of these days. I'm also trying to implement a virtual asynchronous online workshop on my website. I continue to participate at AECT and deliver workshops for various other organizations from time to time. As an answer to the second part of your question, yes I'm enjoying retirement.

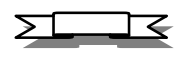

We would like to thank and express our gratitude to Professor Merrill for this enlightening interview. His life is full of accomplishments, and each of his accomplishments opened new horizons in front of many colleagues. He has been one of the most productive scholars in the field of educational technology and instructional design from all aspects including theory, research, and development. It is good to see that Professor Merrill has still a lot of energy as well as excitement for our field and continues to make great contributions. I think he is the living proof that "an educator never retires." 
Correspondence: Ali Simsek, Professor, Faculty of Communication Sciences, Anadolu University, Yunus Emre Campus, Eskisehir, 26470, Turkey. 